\title{
The Role of Community Radio for Integrated and Sustainable Development in Ethiopia: A Critical Review on the Holistic Approach
}

\author{
Destaw Bayable Yemer \\ Guna Tana Integrated Field Research \& Development Center, Debre Tabor University, Ethiopia \\ Email: kiyafeama@gmail.com
}

\begin{abstract}
Community radios play a paramount role in the development of the community. Community radio stations have been highly engaged in addressing social, economic, cultural, educational, health, environmental, sanitation, and disaster issues effectively and strategically using local languages in context. Community radios are also used to express, and share indigenous views, thoughts, ideas, problems, and perspectives of local people. The purpose of this analysis is to explore the role of community radio for integrated and sustainable development in Ethiopia. It used a systematic narrative review. Nine research works and five assessments report were selected purposively and analyzed in a quantitative approach. Currently, in Ethiopia, there are 50 community radio stations that received broadcast licenses from Ethiopian Broadcast Authority with four types of licensing and broadcasting in 29 local languages. Community radio helps the community to identify their common goals, create holistic plans, monitor the progress of their developmental activities, and guide on sustainable development. It contributes to integrated and sustainable development in a collaborative and creative process that cultivates the social, economic, and political conditions needed for the community to succeed which aimed to improve and sustain the livelihoods of the community. However, the media can't achieve its target goal to support the development activities and bring holistic development of the community. As a result; this review paper focuses on reviewing how Ethiopians use community radios for holistic development. And it suggested the way how we can use community radios for the prospective holistic development in Ethiopia.
\end{abstract}

Key words: Community Radio, Holistic Development, Integrated Development, Sustainable Development, Community Radio Practices

\section{Introduction}

In Ethiopia, media history goes with the literacy that started before the birth of Christ around 1000 B.C but officially known after Christianity arrived in Ethiopia that is around the 4th C. in the time of Abrha and Asbeha (373-378). Traditional and modern media have an equal function in a country. Currently, folk and modern media serve as a source of information, and they have much significance to the community in development activities. Modern media was introduced in Ethiopia a century ago, during the reign of Menelik II (1889-1913). The development and practices of Ethiopian media have a long history that has been attached to church literacy. On the other hand, it was attached to the political ideology and philosophy of the governor in the three regimes; monarchial, socialist, and social democrat. Ethiopian media theories and practices still have a relationship with religion, politics, and cultures (Nigussie, 2014). 
Currently, in Ethiopia, there are numbers of media outlets that are owned by the government/state-controlled media (10 broadcast corporates and Media agencies, 5 educational radios, 10 regional TV), privately owned commercial media (13 radio, 20 TV), and communitycontrolled (50 Community radios stations) ownerships. Almost all national and regional media are owned and run by the ruling party of the state. Mean that in Ethiopia there are three media ownership; government/public, private, and community. Government media ruled and run by the ruling party, EPDRF. Accordingly, most of the private media houses have been established in the capital, Addis Ababa for the sake of business activities. Hence the best alternative to use media for development is community media. Radio is important for diversified and heterogeneous literate and illiterate audiences to create awareness about development; widespread tool of information transfer about social, economic, and political aspects.

In light of this, ownership, decentralization, coverage, and language are the most preferable to use community media for holistic development. Community radio stations have legal acceptance and provision in Ethiopia as a community media. Media have a relevant role in many aspects of development (UNESCO, 2015), community radio has a great potential to bring change in all aspects of community development which is supported by participatory development communication. UNESCO's interest in communication is holistic: encompasses all aspects of discipline-technology, social, political, and cultural (UNESCO 2002). Capacity development, sustainable development, productivity enhancement, integration, and people's participation are the core elements of integrated community development. Ethiopia has some community radio stations that are partly administered by the community without the local government interferences. If the country uses the community radio properly, it will bring change in a community. Ethiopian Broadcast Authority (EBA) has begun formally licensing the community radio in 2006 (Getahun, 2006 and Destaw, 2012); they are well established and structured (Mulatu, 2018). Nevertheless, most of the community radios have started properly functioning in 2010 and 2011 (Infoasaid 2011). Currently, there are more than 50 community radio stations that are functioning well across the country (EBA, 2019). However, the community radio stations couldn't support the development of the community to bringing integrated and sustainable development. In consideration of this, the analysis tried to address the following basic questions.

- What the studies said about Ethiopian community radios? 
- What types of strategies community radios use for holistic development?

- How we can use community radios for prospective holistic development in Ethiopia?

\section{Objective}

The main objective of this analysis is to explore the role and effectiveness of community radio stations for integrated and sustainable community development in Ethiopia. It also tried to address the following specific objectives:

- To identify the capacities of Ethiopian community radio stations

- To label the distribution and owners of the community radio stations

- To find out the challenges of the community radio to use for development

- To explore how community radio play for the development of democracy

- To suggest how can we use community radio for prospective integrated development

\section{Method}

To answer the above basic questions of community radio stations' role for integrated and sustainable development, a systematic narrative review method is used. Systematic reviews are best suitable for focused topics (Collins \& Fauser, 2005). This review was summarized different primary studies from which conclusions may be drawn into a holistic interpretation contributed by the reviewers' own experience, existing theories, and models (Campbell Collaboration, 2001). There are different research works conducted on the Ethiopian community radio stations in different topics and themes; nevertheless, the researcher selected only the researches which focused on the strategies and roles of community radio applicability purposively. Based on this, nine research works and five assessment reports were used as the subject of the review. The selected research works reviewed qualitatively based on the conceptual framework of studies. The meta-ethnography method was used to analyze the findings of the researchers and the literature that narrates the role of community radio for integrated and sustainable development in the frame of developmental communication. Besides, different professionals' expertise arguments and essays were considered for the analysis of this review.

\section{Discussions}

\subsection{The Practices of Ethiopian Community Radio}

In Ethiopia, there are numbers of community radios allocate for marginalized areas and people. Intentionally, community radio is reflecting and promoting local identity, character, and culture in focus local contents, create the diversity of voices and opinions, encourage open dialogue and democratic process, promote social change and development as well as good governance and civil society (Fraser \& Restrepo-Estrada, 2002). 
Ethiopian community radio directive (2011) assured the above idea and further elaborated on Article 4, community radio is aimed at providing information, education, and entertainment services for inaccessible communities. It has been promoting development, good governance, language, and culture of the community in the form of community participation. This communication access and participation enables the community to involve in participatory democracy. If the community has access to media, which is placed in the hand of the community, they can convey their views, attitudes, and opinions to others freely. It enables the community to participate in the socio-political and socio-economic sphere of the country.

In community media, individuals have access to media and they are active in participation in principle; however, the practices of community media in Ethiopia didn't endorse the access of media to the community (Destaw, 2012; Jemal, 2018). Accordingly, low public awareness regarding the role of community radio; and community participation in the establishment and management of the stations is very limited. Besides, amateur journalists have not received adequate training, and they lack the knowledge to improve their skills and meet the growing demands of their communities (IMS, 2019).

Moreover, communication access and participation threaten the vested interest of different groups. The decentralization nature of the station, language diversity, cost-effectiveness, and inclusiveness nature of the community radio is the best and effective means for the development of rural people. The radio stations had a variety of program schedules that tried to touch different issues: health, education, agriculture, governance and peace, culture, gender/women, youth, children, law, elders, and disables (IMS 2019). Most of the community radio stations have been established out of the capital city, Addis Ababa. Even if they established in marginalized areas that have not much media coverage and access, they are controlled by the central and regional party-political governor in means of intervention politically. Thus, they are decentralized and controlled. The local authority and the political leaders' intervention is the challenge to use the community radio for development (Jemal, 2018); nonetheless, the station managers said that they have never faced direct intervention/interference or sanction from local government (IMS, 2019).

Community radio provides need-based location-specific information with local participation in content development and broadcasting because of the community radio station as "one that is operated in the community, for the community, about the community, and by the community" 
(Tabing, 2002:9). Hence, media access prefers community need-driven information access that incites for development.

Table 1: Ethiopian Community Radio Stations List with detail description

\begin{tabular}{|c|c|c|c|c|c|c|c|}
\hline$\#$ & Name of the Radio station & Region & Owner & $\begin{array}{l}\text { Date of } \\
\text { license in } \\
\text { E.C }\end{array}$ & $\begin{array}{l}\text { Licensing } \\
\text { number }\end{array}$ & Frequency & $\begin{array}{l}\text { Broadcast } \\
\text { language }\end{array}$ \\
\hline 1 & $\begin{array}{l}\text { Kore Worda and its } \\
\text { surrounding community radio } \\
\text { station }\end{array}$ & $S N N P$ & $\begin{array}{l}\text { Korie worda and } \\
\text { surrounding community }\end{array}$ & 1998 & $06 / 1991$ & FM92.3 & $\begin{array}{l}\text { Korete and } \\
\text { Amharic }\end{array}$ \\
\hline 2 & $\begin{array}{l}\text { Kembata Worda and its } \\
\text { surrounding community radio } \\
\text { station }\end{array}$ & $S N N P$ & $\begin{array}{l}\text { Kembata and } \\
\text { surrounding community }\end{array}$ & 2000 & $19 / 2000$ & $F M 105.5$ & Kenbategna \\
\hline 3 & Kafa community radio station & SNNP & Kefa community & 2000 & $20 / 2000$ & FM 102.5 & kefigna \\
\hline 4 & $\begin{array}{l}\text { Jimma University institute of } \\
\text { higher education community } \\
\text { radio station }\end{array}$ & Oromia & Jimma University & 2000 & $21 / 2000$ & FM 102.0 & $\begin{array}{l}\text { Amharic } \\
\text { Oromifa }\end{array}$ \\
\hline 5 & $\begin{array}{l}\text { Kombolicha community radio } \\
\text { station }\end{array}$ & Amhara & $\begin{array}{l}\text { Kombolicha Town and } \\
\text { surrounding community }\end{array}$ & 2000 & $23 / 2000$ & FM 104.8 & $\begin{array}{l}\text { Amharic and } \\
\text { Oromifa }\end{array}$ \\
\hline 6 & Sudie community radio station & Oromia & Sudie worda community & 2001 & $27 / 2001$ & $F M 103.5$ & Oromifa \\
\hline 7 & $\begin{array}{l}\text { Waghimira community radio } \\
\text { station }\end{array}$ & Amhara & Waghimira Community & 2002 & $30 / 2002$ & $F M 92.7$ & $\begin{array}{l}\text { Himitegna, } \\
\text { Amharic, } \\
\text { Tigiregna, Awigna }\end{array}$ \\
\hline 8 & $\begin{array}{l}\text { Argoba community radio } \\
\text { station }\end{array}$ & Afar & Argoba Community & 2002 & $31 / 2002$ & $F M 98.6$ & Argobigna \\
\hline 9 & $\begin{array}{l}\text { Civil Service University } \\
\text { community radio station }\end{array}$ & Addis Ababa & $\begin{array}{l}\text { Ethiopian Civil Service } \\
\text { University }\end{array}$ & 2002 & $33 / 2002$ & FM 100.5 & $\begin{array}{l}\text { Amharic and } \\
\text { Oromifa }\end{array}$ \\
\hline 10 & $\begin{array}{l}\text { Setit Humera community Radio } \\
\text { station }\end{array}$ & Tigiray & $\begin{array}{ll}\text { Settit } & \text { Humera } \\
\text { community } & \end{array}$ & 2003 & $34 / 2003$ & FM 106.9 & Tigiregna \\
\hline 11 & $\begin{array}{l}\text { Haromaya university } \\
\text { community radio station }\end{array}$ & Oromia & Haromaya University & 2004 & $35 / 2004$ & $F M 91.5$ & $\begin{array}{l}\text { Amharic, Oromifa } \\
\text { and English }\end{array}$ \\
\hline 12 & $\begin{array}{l}\text { Hawassa University higher } \\
\text { education institute community } \\
\text { radio station }\end{array}$ & SNNP & $\begin{array}{l}\text { Hawassa University and } \\
\text { surrounding community }\end{array}$ & 2004 & $36 / 2004$ & $F M 90.9$ & $\begin{array}{l}\text { Amharic and } \\
\text { English }\end{array}$ \\
\hline 13 & $\begin{array}{l}\text { Qebri dehar university } \\
\text { community radio station }\end{array}$ & Somalia & Qebridehar University & 2004 & $37 / 2004$ & $F M 90.8$ & $\begin{array}{l}\text { Somaligna and } \\
\text { Amharic }\end{array}$ \\
\hline 14 & $\begin{array}{l}\text { Wollega University community } \\
\text { radio station }\end{array}$ & Oromia & $\begin{array}{l}\text { Wolega University and } \\
\text { the community }\end{array}$ & 2004 & $38 / 2004$ & $F M 89.0$ & $\begin{array}{l}\text { Amharic, Oromifa, } \\
\text { and English }\end{array}$ \\
\hline 15 & $\begin{array}{l}\text { Addis Ababa University } \\
\text { institute of higher education } \\
\text { Community radio station }\end{array}$ & Addis Ababa & Addis Ababa University & 2005 & $41 / 2005$ & $F M 99.4$ & Amharic \\
\hline 16 & Bahir Dar University and its & Amhara & Bahir dar University & 2006 & $42 / 2006$ & $F M 93.3$ & Amharic \\
\hline
\end{tabular}




\begin{tabular}{|c|c|c|c|c|c|c|c|}
\hline & $\begin{array}{l}\text { Surrounding Community radio } \\
\text { station }\end{array}$ & & $\begin{array}{l}\text { and surrounding } \\
\text { community }\end{array}$ & & & & \\
\hline 17 & $\begin{array}{l}\text { Dibate worda and its } \\
\text { surrounding community radio } \\
\text { station }\end{array}$ & Binshangul & $\begin{array}{l}\text { Dibate worda and } \\
\text { surrounding community }\end{array}$ & 2007 & $47 / 2007$ & FM 93.7 & $\begin{array}{l}\text { Gumizigna, } \\
\text { Shinashigna, } \\
\text { Agawogna, } \\
\text { Oromifa and } \\
\text { Amharic }\end{array}$ \\
\hline 18 & $\begin{array}{l}\text { Gamibela town and its } \\
\text { surrounding community radio } \\
\text { station }\end{array}$ & Gamibella & $\begin{array}{l}\text { Gamibela Town and } \\
\text { surrounding community }\end{array}$ & 2007 & $48 / 2007$ & $F M 93.2$ & $\begin{array}{l}\text { Agnuwak, Nuwire, } \\
\text { Amharic }\end{array}$ \\
\hline 19 & $\begin{array}{l}\text { Guba community focused } \\
\text { community administrator radio } \\
\text { station }\end{array}$ & Binishangul & $\begin{array}{l}\text { Guba community and } \\
\text { local administrator }\end{array}$ & 2007 & $47 / 2007$ & $F M 1002.2$ & $\begin{array}{l}\text { Gunizgna and } \\
\text { Amharic }\end{array}$ \\
\hline 20 & $\begin{array}{l}\text { Konso local administration } \\
\text { community radio station }\end{array}$ & SNNP & Konso community & 2007 & $50 / 2007$ & FM 103.7 & $\begin{array}{l}\text { Afakonso and } \\
\text { Amharic }\end{array}$ \\
\hline 21 & $\begin{array}{l}\text { Uba Debre Tsehay worda and } \\
\text { its surrounding community } \\
\text { radio station }\end{array}$ & SNNP & $\begin{array}{l}\text { Uba debre tsehay worda } \\
\text { community }\end{array}$ & 2007 & $54 / 2007$ & FM 103.1 & $\begin{array}{l}\text { Gofa Gzogna, } \\
\text { Arigna, Amharic }\end{array}$ \\
\hline 22 & $\begin{array}{l}\text { Semera city and surrounding } \\
\text { administrator community radio } \\
\text { station }\end{array}$ & Afar & $\begin{array}{l}\text { Semera town and } \\
\text { surrounding } \\
\text { administrator }\end{array}$ & 2007 & $52 / 2007$ & $F M 90.6$ & $\begin{array}{l}\text { Afarigna and } \\
\text { Amharic }\end{array}$ \\
\hline 23 & $\begin{array}{l}\text { Finote selam City adimistration } \\
\text { and its surrounding community } \\
\text { radio station }\end{array}$ & Amhara & $\begin{array}{l}\text { Finote selam city } \\
\text { administration and local } \\
\text { administrator }\end{array}$ & 2007 & $53 / 2007$ & $F M 98.8$ & Amharic \\
\hline 24 & $\begin{array}{l}\text { Adola Redie communities and } \\
\text { administration community } \\
\text { radio station }\end{array}$ & Oromia & $\begin{array}{lr}\text { Adola } & \text { Rredie } \\
\text { communities } & \text { and } \\
\text { administration } & \end{array}$ & 2007 & $56 / 2007$ & $F M 89.8$ & $\begin{array}{l}\text { Oromifa } \\
\text { Amharic }\end{array}$ \\
\hline 25 & $\begin{array}{l}\text { North Ari worda and its } \\
\text { surrounding community radio } \\
\text { station }\end{array}$ & SNNP & $\begin{array}{l}\text { North Ari Worda and } \\
\text { surrounding community }\end{array}$ & 2007 & $55 / 2007$ & FM 93.9 & $\begin{array}{l}\text { Arigna } \\
\text { Amharic }\end{array}$ \\
\hline 26 & $\begin{array}{l}\text { Debre markos university } \\
\text { institute of higher education } \\
\text { community radio station }\end{array}$ & Amhara & $\begin{array}{lr}\text { Debre } & \text { Markos } \\
\text { University } & \text { and } \\
\text { surrounding } & \text { community }\end{array}$ & 2007 & $51 / 2007$ & $F M 97.7$ & Amharic \\
\hline 27 & $\begin{array}{l}\text { Chewaka Worda community } \\
\text { radio station }\end{array}$ & Oromia & $\begin{array}{l}\text { Chewaka worda } \\
\text { community association }\end{array}$ & 2008 & $59 / 2008$ & FM 92.1 & Oromifa \\
\hline 28 & $\begin{array}{l}\text { Injibara community radio } \\
\text { /Injibara FM/ }\end{array}$ & Amhara & $\begin{array}{l}\text { Injibara city and } \\
\text { surrounding community }\end{array}$ & 2008 & $63 / 2008$ & FM 104.1 & $\begin{array}{l}\text { Amharic } \\
\text { Agawugna }\end{array}$ \\
\hline 29 & Silite community radio /FM & SNNP & Silite community & 2008 & $67 / 2008$ & $F M 92.6$ & $\begin{array}{l}\text { Silitegna } \\
\text { Amharic }\end{array}$ \\
\hline 30 & Lasika Community radio /FM & SNNP & Basiketo community & 2008 & $68 / 2008$ & FM 99.6 & $\begin{array}{l}\text { Basikitogna and } \\
\text { Amharic }\end{array}$ \\
\hline 31 & Sheka Community radio /FM & SNNP & Sheka city & 2008 & $69 / 2008$ & FM 98.6 & Shekitogna \\
\hline
\end{tabular}




\begin{tabular}{|c|c|c|c|c|c|c|c|}
\hline & & & $\begin{array}{l}\text { surrounding } \\
\text { administrators }\end{array}$ & & & & \\
\hline 32 & Rayitu community radio /FM & Oromia & Rayitu Gelbe community & 2008 & $71 / 2008$ & FM89.0 & Oromifa \\
\hline 33 & $\begin{array}{l}\text { Gidami worda community } \\
\text { radio station }\end{array}$ & Oromia & Gidami worda & 2008 & $72 / 2008$ & $F M 94.3$ & Oromifa \\
\hline 34 & Erob community radio /FM & Tigiray & Erob community & 2008 & $73 / 2008$ & $F M 92.3$ & $\begin{array}{l}\text { Hosanna and } \\
\text { Tigiregna }\end{array}$ \\
\hline 35 & $\begin{array}{l}\text { Mittu University community } \\
\text { radio }\end{array}$ & Oromia & Mittu university & 2008 & $74 / 2008$ & $F M 95.6$ & $\begin{array}{l}\text { Oromifa, Amharic } \\
\text { and English }\end{array}$ \\
\hline 36 & Kunama community radio /FM & Tigiray & Kunama community & 2008 & $75 / 2008$ & FM 97.9 & $\begin{array}{l}\text { Kunamigan and } \\
\text { Tigiregan }\end{array}$ \\
\hline 37 & $\begin{array}{l}\text { Wolidia community radio } \\
\text { /Wolidia } F M\end{array}$ & Amhara & $\begin{array}{l}\text { Wolidia } \text { University and } \\
\text { North Wollo Zone } \\
\text { Administration }\end{array}$ & 2008 & $76 / 2008$ & $F M 89.2$ & Amharic \\
\hline 38 & Kemisie community radio /FM & Amhara & Kemisie community & 2008 & $77 / 2008$ & FM101.0 & $\begin{array}{l}\text { Oromifa and } \\
\text { Amharic }\end{array}$ \\
\hline 39 & Wolaita Wogeta FM & SNNP & Wolaita Community & 2009 & $78 / 2009$ & $F M 96.6$ & $\begin{array}{l}\text { Wolaitegna and } \\
\text { Amharic }\end{array}$ \\
\hline 40 & Sogie FM/community radio & Benishangual & $\begin{array}{l}\text { Ybelo Jigayinfoy worda } \\
\text { community }\end{array}$ & 2009 & $79 / 2009$ & $F M 95.3$ & $\begin{array}{l}\text { Gumizgna, Amharic } \\
\text { and Oromifa }\end{array}$ \\
\hline 41 & Fik community radio station & Somalia & Fik community & 2009 & $83 / 2009$ & $F M 93.3$ & Somaligna \\
\hline 42 & Hadegala community radio & Somalia & $\begin{array}{l}\text { Yehagala community } \\
\text { association }\end{array}$ & 2009 & $84 / 2009$ & FM 101.7 & Somaligna \\
\hline 43 & Dillo worda community radio & Oromia & Dillo worda & 2009 & $87 / 2009$ & $F M 100.1$ & $\begin{array}{l}\text { Oromifa, Amharic } \\
\text { and English }\end{array}$ \\
\hline 44 & $\begin{array}{l}\text { Jigjiga its surrounding } \\
\text { community } \\
\text { radio station }\end{array}$ & Somalia & $\begin{array}{l}\text { Jigjiga university and } \\
\text { surrounding community }\end{array}$ & 2009 & $88 / 2009$ & FM 96.1 & $\begin{array}{l}\text { Somaligna and } \\
\text { Amharic }\end{array}$ \\
\hline 45 & $\begin{array}{l}\text { Mekele university community } \\
\text { radio station }\end{array}$ & Tigiray & Mekele university & 2009 & $89 / 2009$ & $F M 96.4$ & $\begin{array}{l}\text { Amharic and } \\
\text { Tigiregna }\end{array}$ \\
\hline 46 & $\begin{array}{l}\text { Dilla university its surrounding } \\
\text { community radio station }\end{array}$ & SNNP & Dilla university & 2010 & $90 / 2010$ & $F M 89.0$ & $\begin{array}{l}\text { Amharic, Ediffao, } \\
\text { Oromifa }\end{array}$ \\
\hline 47 & $\begin{array}{l}\text { Hawassa Industry park } \\
\text { community radio station }\end{array}$ & SNNP & $\begin{array}{l}\text { Hawassa Industry } \\
\text { community }\end{array}$ & 2010 & $91 / 2010$ & FM 102.4 & Amharic \\
\hline 48 & FM Segele Adama & Oromia & $\begin{array}{l}\text { Adama's voice } F M \\
\text { association }\end{array}$ & 2010 & $93 / 2010$ & FM 100.7 & $\begin{array}{l}\text { Amharic, Oromifa } \\
\text { and English }\end{array}$ \\
\hline 49 & Axum university community & Tigiray & Axusm university & 2011 & $112 / 2011$ & FM 93.6 & $\begin{array}{l}\text { Tigiregan and } \\
\text { Amharic }\end{array}$ \\
\hline 50 & Raya community radio & Tigiray & Raya University & 2005 & $05 / 2005$ & FM 90.9 & $\begin{array}{l}\text { Amharic and } \\
\text { Tigiregna }\end{array}$ \\
\hline
\end{tabular}


Ethiopian Broadcast authority gave legal licenses for 50 community radio stations at the end of 2020. As they indicate in the following fig 1, they are established in different parts of the state; 13 in South Nation and Nationalities Region, 11 in Oromia Region, 9 in Amhara Region, 5 in Tigiray Region, 4 in Benishangul Gumiz Region, 2 in Addis Ababa City Administration, 2 in Afar Region and 1 in Gamibella Region.

Figure 1: Ethiopian Community Radio Stations Distribution

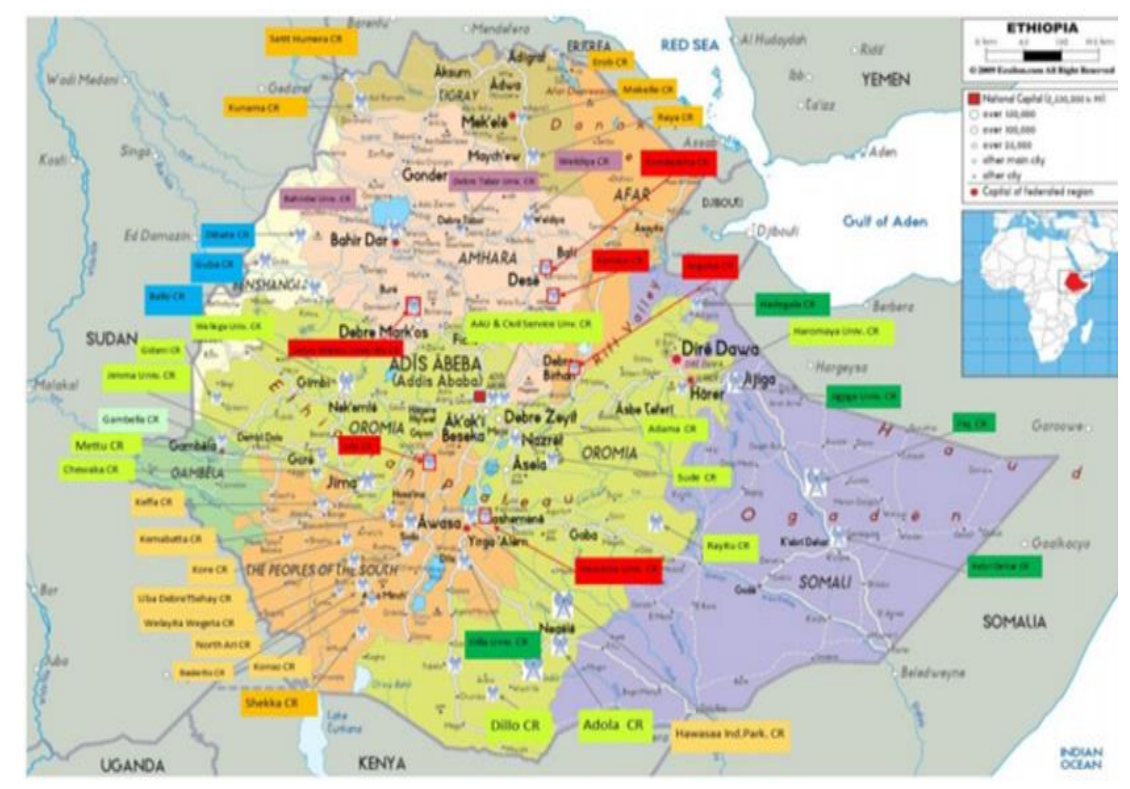

Source: IMS Assessment Report of 2019: https://www.mediasupport.org/wp-content/uploads/2019/04/Ethiopiacommunity-radio-assessment_IMS_April2019.pdf

Among 50 Ethiopian community radio stations, $36 \%$ were owned by the community association, $34 \%$ by the community and local administration, $24 \%$ by universities and their surrounding communities, $4 \%$ by higher education, and $2 \%$ by common interest group (IMS, 2019). Within these, $62 \%$ of them are broadcasted, $34 \%$ prepared to broadcast and the rest $4 \%$ registration canceled. Most of the community radio stations are administered by local administrators and higher educational institutions. Even if they fulfill the criteria that are approved by EBA, they didn't practice accordingly in the rule of law; the community can't manage and administer the station.

The access of the community radio station is limited in Ethiopia when we compare the current coverage and need of the community. Nation and nationalities in Ethiopia haven't got enough media access and coverage in consider of their language, culture, and activities. The topography of the state, the antenna that planted, the local languages, color, and personality were low (Destaw, 2012). Also, the interaction of the producers and audience, and the feedback access was 
limited (Destaw, 2012; Kalikidan, 2018; Dawit, 2019). However, community radio concerned the access, voices; diversity, creativity, and participation are the fruits of community radio for local communities to voice their issues, concerns, cultures, traditions, and languages (Jemal, 2018).

Accordingly, Jemal (2013) was stated the basic problems to use community radio for development in a country; the number of community radio broadcasters were significantly low, the experience and knowledge in managing and running its programs were insufficient, and to set up community radio for all most each language speaker or ethnic group demands huge investment. The other challenge of community radio stations were insufficient knowledge about the structural framework, absence of internal procedures, frequent failure of technical equipment, lack of studio materials spare parts and guidance, low commitments of the voluntary staffs, lack of transportation services to access remote communities, and low broadcast and program quality (IMS, 2019). Distances of the stations to the community and coverage and time limitation are other basic problems. Almost all community radio stations were planted in the zonal town and district level. Their coverage was also limited in case of a geographical problems; they had a 1watt transmission capacity which they have not used all their potential. According to the community radio directive, $60 \%$ of programing focuses on local issues and $40 \%$ on national and international issues. However, in practical aspects, it is vice-versa (IMS 2019).

Thus, the challenges are legal, operational, human resource, financial, administrative infrastructures, and other related problems that have to be solved by the government, NGOs, and local communities to use community media for integrated and sustainable development of the country. However, the aforementioned challenges were not solved easily to use community radio for development.

Nowadays, Ethiopia had 50 licensed community radio stations broadcasted in 29 local, national, and international languages (IMS 2019). It shows the potentials of the community radio stations how to address the information in a wider context. Furthermore, participation in production and management is essential in the community radio. One of the unique characteristics of $\mathrm{CR}$ is the active participation of the community in every process of the station (Tabing, 2002). The community has a full mandate to participate in all levels of the radio station activities (ibid). In most community radio stations in Ethiopia, the community participation was low (Destaw, 2012; Jemal, 2018 and Dawit, 2019) in administration and financing, but Fraser and Estrada (2002) recommended that the community have to participate in administrating and financing the radio 
stations. Community radio communication is need-based, indigenous, self-reliant, and ecologically sound (Servaes, 1996).

Ethiopian community radio station in the principles focused on infotainment and edutainment programs (Kassahun, 2012); however, access, participation, and personals were limited to address its program to the audience (Dawit, 2019). Community radio is a powerful tool to informing the community on current issues that are crucial to the rural livelihoods, an agent of social change, a tool of conflict management, and conflict resolution (Castello, 2003). It allows farmers to become 'little journalists' (Jemal, 2018). Citizen journalism is practiced freely in the community radio stations in form of dialogical communication, two-way communication.

According to Mulatu (2018), community radio is the best platform for dealing with internal conflicts in social issues. It has the power to solve the internal conflicts: inter and intra conflicts which focused on political, socio-economic, border, and administrative structure, ethnic and religious tensions, the geopolitics of the country, and other causes. The nature of approaches and autonomy of the community radio can perform better than the mainstream media (Ibid). In Ethiopia, community radio ownership, control, proximity, immediacy, voluntarism, and nonprofitable is advantageous over mainstream media Ethiopia (Mulatu, 2018). Owning and controlling the means of communication is a very basic idea of community media. Ownership, proximity, immediacy, language, and value of the community are the community radio benefits (Tabing, 2002; Moges, 2018). The station is the community, the program that broadcasted is their issues and the journalists are from them, so they have to account for the community and their concerns.

Ethiopia faced many political and social problems related to ethnic violence, corruption, nonstop violation which leads to an economic crisis. Community radio should encourage the opendialogue and democratic processes to identify problems, give a solution, and mobilize adequate groups for the action of change (Girard, 2000). Community radio stations provided a platform for the community which was used for interactive discussion, debate, analysis, exchange of ideas and opinions (Kassahun, 2012; Destaw, 2012; Mulatu, 2018; IMS, 2019). This open-dialogue helps the community to be interdependent and interactive in any social issue. The editorial policy of the stations gives the full mandate for the presenters and audience to present balanced programs that present diversified and equal views of the community that had been treated in the station (Destaw, 2012); nonetheless, the practices were different. 


\subsection{Community Radios for Integrated Development}

The basic question here is "how do we use community radio for integrated and sustainable development in structural form?" as a developing country, we have to use it for capacity development, productivity enhancement, integration, sustainable development, people's participatory participation. Ethiopian Broadcast Authority has prepared the community directives and assigns a director for the community radio how they are functioning, but they are not effective in follow up (IMS, 2019). The authority has been missed one thing on the functioning of community radio to use for integrated and sustainable development. The 1960th integrated and need-based approach was advised to use community media for developing countries, CHF was also advised to use a holistic approach for empowerment and development, but the developing countries development agents don't use it properly (Calatrava-Requena, 2018). Besides, the community radio program formats and coverage didn't have parallel structures with Ethiopian community radio directives (IMS, 2019).

As it has been argued by many scholars, holistic development is a collaborative and creative process that cultivates the social, economic, political, cultural, spiritual, and environmental conditions needed for the entire community to succeed. It is a holistic evolution of all aspects of society: political, sociological, psychological, scientific, and cultural advancement of the community (Al-Dahir, Kang, and Bisley, 2009). The community brings holistic development that enables improve infrastructure, better health care, lower crime rates, improve education, and other advancements. When we construct the social capital of the community by providing space for dialogue that helps the community to re-narrate its story, issues and problems are asking critical questions (Freire, 1963).

Community radio is one of the most effective means and alternative forms of communication for the development of rural communities especially in social participation, information, and advice on literacy, health, child care, improved agricultural methods, vocational training, and protection of the environment. The program of community radios is geared towards promoting community development and social empowerment of its audience (Fraser and Estrada, 2002). The community can realize inclusive and can define socio-economic development through their active participation. With respect to this, the grassroots and horizontal levels of communication 
for development are advisable for integrated development. Accessible and simple systems and techniques of communication that enables to inform, motivate, and train rural population increase people's participation in development (Waisboard, 2000). Community radios are advised to use participatory development communication that is need-oriented, endogenous, selfreliant, and ecologically sound and based on participatory democracy and transformations (Servaes, 1996). As a result, it must fulfill the criteria of integrated development; awareness and confidence building, social mobilization for collective action, participatory management: analysis, planning and action, and monitoring (Dhamotharan, 2009).

\subsection{How can we use Community Radio for Prospective Integrated Development?}

The world has turned its face to the use of community radio to bring participatory economic development at a grass-root level in developing countries (Mathewos, 2006). The relevance of community radio in Ethiopia is undeniable, because of the low literacy level, the existence of more than 85 nations and nationalities, poor infrastructure, the infancy of democratization as well as deep-rooted social problems of the nation (Getahun, 2006). Community radio plays important role in the development process and advancement of good governance practices, like harmonious social interaction, economic development, political participation, and the existence of culture and language. Ethiopia as a country has several problems, the one expects from the media is producing informed citizens, brings social development and technological transformation in the means of information dissemination, education, entertainment, and mobilization of the community (Getahun, 2006).

In line with the above assumptions, community radio gives the chance for the community to involve in all aspects of the station management and program production which provides and helps them in the development and social advancement of their community (Fraser and Estrada, 2001). It should create a holistic perception of the local reality and the options for improving it. Community radio in Ethiopia is serving small ethnic groups, which have a strong sense of local identity (Infoasaid, 2011); and it aimed to educate the community, fostering behavioral changes, and empowering the community. The Ethiopian government has to use community radio for integrated and sustainable development besides giving license for the sake of media coverage. EBA (2011) prepared the community radio broadcasting service to play a significant role in fulfilling the education, information, and entertainments needs of the community which the commercial and government broadcasting service do not cover. 
The sense of community radio is interested in holistic approaches: "In the community, for the community, about the community and by the community" (Tabing, 2002, p. 9). It is a medium for the voiceless, to voice their issues, concerns, cultures, traditions, and languages. So that it gives access to voices in the community and encourages diversity, creativity, and participation (Jemal, 2013). The expansion of community radio is one of the best opportunities to use radio for development purposes at the grass-root level (Ibid). Moreover, the community media essence and the holistic approach have similar intentions, applications, and practices.

Community radio helps the community to identify their goals, create holistic plans, monitor the progress of the community development activities, and guide sustainable development. The plan helps to create a shared common understanding of sustainable community success, and it determines and analyzes effective strategy areas for community success (Baxter and Purcell, 2007). This planning will help in bringing the whole community together with capacity development and productivity enhancement of the community.

Most of the community radio stations disseminated social development messages that promote the local language and culture (Kasshun, 2012; Jemal 2018). The program format of the stations was mainly focused on infrastructure projects like health, education, agriculture, good governance, and other social development activities (Ibid). Community radio strives for the development of cultures, languages, education, agriculture, health, democracy, good governances, gender, and youth development. It also can create awareness and motivate the community on development activities. Jemal (2018) points out that community radios are the best alternative to assist sustainable development efforts by helping the self-expression of local people who are often left as voiceless with the mainstream media. It plays an important role by providing public platforms for the advancement of community and set governance agendas that focused on social, political, and economic development. Community media prioritize the local community agendas (IMS, 2019) because the beholder of the station community agenda's gets priority. Ethiopian community radio stations have the potential to play a significant role in providing quality information to citizens and driving public accountability and governance issues through 'citizen-oriented journalism' (Ibid).

In the spirit of this, capacity development and sustainable development are the core for an integrated model which includes; education, health, nutrition, agriculture, housing, security, infrastructure, politics, culture/religion, and recreation. To be effective in the holistic development of the community, the stations' program schedule has to consider the holistic 
approach principles: plain communication strategies, seminar/workshop format, live-service job training, sensitization, research, and documentation.

Based on the elements, the output of the integrated community development aimed to improve and sustain the livelihoods of the community. The living standard of the community must be improved in terms of accessible roads, constant electricity, and power supply, portable drinking water, access to education and health care service, employment opportunities, affordable and comfortable housing, advanced cultural beliefs, good governance, and empowerment of the community members, improved environmental conditions and available and affordable food supply. Development agents and government sectors have to create interaction or coordination for integrated development. To sustain the development, they have to prepare the road map for integrated development with a holistic approach that takes into account the interests, values, ways of thinking, experiences, skills, etc. of all the community members. Accordingly, it requires a need assessment survey to redefine the predominant patterns of distribution of wealth of the community. It helps to know what type of scarcity has and prepare an appropriate plan to fulfill it.

Integrated and sustainable development will determine the approaches that we use and the plans we applied. As seven D approach principles approached, appreciating the existing capacities of the community values and cultures is essential. Processing and creating avenues to increase the participation, knowledge, and reflection of the community develop capacities to initiate and manage changes. These functions are important in community radio stations for holistic development (Dhamotharan, 2009). Different development frameworks for strategic sustainable development have to address to the community. As Robert, et-al (1997) stated the five levels (system, success, strategic, action, and tools), the community radios have to address and have to create a holistic understanding in the community.

To clarify the above ideas, the community has to understand the system level with the innovative approach, the strength of creating community awareness and allowing for social mechanisms, self-organization, interdependence, and diversity, through participation, equal representation, and collaboration (Dhamotharan, 2009). The media have to create a broad and common vision of community development where a community can manage and allocate their resources to achieve identified needs. Developing community members' capacity to identify and meet their own needs through diverse participation and representation are other mechanisms. This approach establishes a transparent democratic atmosphere that provides a positive attempt towards 
changing community members' mindsets. The open participatory process can allow the community members to freely elect their representatives, and they can discuss the community's needs in democratic ways. This action can build the democratic process and create a sense of community ownership for the community project which is subsequently completed, monitored, and evaluated. The approach also clusters communities together to share resources and exchange benefits among communities. The tools level assessing completed community projects and evaluating the effectiveness project. These levels have to support by the media in form of development advocacy.

The holistic approach emphasized the involvement of the community members in participating programs and activities for the provision of human needs of physical infrastructures, emotional, socio-political, economic, and technology enterprise of the people concerned (Akinyemi, 1997). According to Imhabekhai (2009), integrated community development is an effective tool for promoting peace, justice, equality, and happiness.

Thus, all people have the chance to participate equally in their development and societal growth. Sustainable development requires the recognition of intergenerational equality, which implies the assumption as an ethical imperative of respect the generation in consider of a healthy environment, but it also the right of forthcoming generations to inherit from present generations, a healthy and ecologically balanced environment. In sustainable development, the community livelihood options have to be making balanced in consideration of their natural resources. It requires that communities be self-sufficient, that people's control over their own lives is increased, and that the social and cultural identity and decision-making capacities of societies be preserved and reinforced. As a holistic process, sustainable development requires an indissoluble dialectic union between theory and practice. This, in turn, implies a dynamic process undergoing constant progression and modification (Kapur, 2015).

\section{Conclusions}

Community radio has a great contribution to integrated and sustainable development with holistic approaches in a collaborative and creative process that cultivates the social, economic, political, cultural, spiritual, and environmental conditions needed for the entire community to succeed. It can be used for development, social participation, information, and advice on literacy, health, child care, improved agricultural methods, vocational training, and protection of the environment in local communities. Community radio is essential for participatory development 
communication which is need-oriented, indigenous, self-reliant, and ecologically sound and based on participatory democracy and structural transformations. It also gives high emphasis on edutainment, infotainment, and localism programs. The radio stations have to prioritize the local community agendas: promoting healthy communities, good governance, justice, human rights, civic participation, languages, cultures, identities, social values and traditions, peace, tolerance, and pluralism at the grass-root level. This is the mechanism to put the alternative livelihood options to make self-balanced communities in Ethiopia is a community radio role. The radio stations have to strive to create a moderate society that enhances the capacity of decision making. To use community radio for development, Community radio challenges: legal, operational, human resource, financial, administrative, infrastructures, and other related problems have to be solved. These problems have to be solved by the government, NGOs, and local communities to use community media for integrated and sustainable development of the country. The stations confront the challenges and tried to do their activities effectively even if they had limitations.

\section{Recommendations}

Community radio stations are effective for the integrated and sustainable development of the community. The holistic approach should be functional to achieve the prospective development of Ethiopia. It should have developed the capacity of the community in form of holistic approaches that emphasize the lives of the community to enhance self-sufficient. Community radio is in the community which helps them as eye, ear, and mouth of a community to lead them on the right track of the development. The communication nature must be indigenous and needbased which motivates and enhances the community to increase productivity.

Ethiopian Broadcast Authority (EBA) also should give full rights to the community to run the radio stations and have to promote the good reputability of community radios to the community. EBA has to prepare a road-map with different development agents to use community radio for integrated development which focused on the community needs. Besides, the community has to finance the stations and invite local NGOs to give different training for the community on how to manipulate the station. On the other hand, local administrators have to avoid their interruption and assign cabinets to administer the radio stations; the community board members also have to handle the station and follow-up on the stations' activities. Editorial independence and ownership of the station must be handled by the station board members. The stations have to provide access for the community to participate in the station in a two-way 
symmetric communication system and provide platforms for the community discussion. For further improvements, scholars have to conduct researches on community radios for future uses how community radio uses for empowerment, sustainable developments, democracy, good governances, gender equalities, economic developments, etc. to do with the local community eco-setting.

\section{References}

Akinyemi, V.I (1997). Evaluation and monitoring techniques in community development: In S.A Makinde (eds) Educational theory and practice in Nigeria. Benin. New Era Publishers.

Al-Dahir Ali, Kang Hye-Jeong, and Bisley Nicholas. (2009).A Holistic Approach to Sustainable Community Development in the Developing World. Karlskrona, Sweden: School of Engineering Blekinge Institute of Technology.

Baxter, K. H., \& Purcell, M. (2007). Community sustainability planning. Municipal World, 117(11), 35-38.

Birhanu Olana (2009). Journalism in the Context of Ethiopian Mass Media: essays, Researches and reflections. Addis Ababa.

Bruce Girar (2000). ADIO CHAGUARURCO, ECUADOR-NOW YOU'RE NOT ALONE, community radio case study.

Calatrava-Requena Javier. (2018). Integrated Development and Basic Needs Approach: Analysis of Its Application to Rural Areas (1965-1985): https://www.researchgate.net/publication/332247761.

Campbell Collaboration (2001). Campell Collaboration guidlines. www.campelcollaboration.com, Retrived Feb 14, 2006.

Collins A., \& Fause. C. (2005). Balancing the strengths of systematic and narrative reviews. Human Reproduction, 11(2),103-104.

Dawit Kebede. (2019). Audience Participation in Community Radio: Ethiopian Civil Service University's Community Radio FM 100.5 in Focus. Addis Ababa University.[Unpublished]. 
Destaw Bayable. (2012). A study on the practice of Kombolcha Community Radio. Addis Ababa University.[Unpublished].

Dhamotharan Mohan. (2009). Handbook on Integrated Community Development-Seven D Approach to Community Capacity Development. Japan: Asian Productivity Organization. ISBN: 92-833-7085-6.

EBA. (2016). Report about the community radio in 2016.Ethiopian Broadcast Authority, Addis Ababa

EBA. (2019). Report about the community radio in 2019. Addis Ababa: Ethiopian Broadcast Authority.

Fraser \& Estrada (2001). Community Radio Hand Book. Chaple Hill University center for International Studies, UNESCO.

Fraser Colin and Restrepo-Estrada Sonia. (2002). Community Radio for Change and Development: Society for International Development. SAGE Publications (London, Thousand Oaks, CA and New Delhi), 1011-6370 (200212) 45:4; 69-73; 030175.

Freire Paulo. (1963). PEDAGOGY of the OPPRESSED. United Nation: Library of Congress.

Freire Paulo. Pedagogy of Freedom: Ethics, Democracy, and Civic Courage: https://love2justice.wordpress.com/2016/05/06/what-is-holistic-community-development

Getachew Metafaeria (2003). Status of Media in Ethiopia, (P561-569) Encyclopedia of International Media and Communications, Vol 1. Elsevier Science.

Getahun Nigatu (2006). The Theory and Practice of Community Radio: the case of Sidama and Kore radio development initiative. Addis Ababa University.[Unpublished].

Imhabekhai, C.I (2009). Management of community development programmes and projects. Benin. University of Benin Press

IMS. (2019). Assessing the capacity, challenges and sustainability of the community radio sector in Ethiopia . Danicom.net communication and development.

Infoasaid. (2011). ETHIOPIA media and telecoms landscape guide. Addis Ababa 
Jemal Mohammed (2013). Challenges and Opportunities in the Use of Radio Broadcast for Development in Ethiopia. Online Journal of Communication and Media Technologies, Volume: 3; Issue 2.

Jemal Mohammed (2018). The use of community radio to support local development efforts in Ethiopia: the case of Waghimira community radio. urnalKomunikasi. Malaysian Journal of Communication. Jilid 34(2),188-204

Joe D. (2019). What is holistic community development?: https://love2justice.wordpress.com/2016/05/06/what-is-holistic-community-development/

Kalkidan Hailu (2018). A Study on the Access, Participation and Platform of Addis Ababa University Community Radio. Addis Ababa university. .[Unpublished].

Kapur. (2015) Approaches and Strategies for Holistic Social Development. Arts Social Sci J 6: 119. doi:10.4172/2151-6200.100011 9

Kassahun Wodajo. (2012). Community Radio for Social Development: the case of Jimma community radio. Addis Ababa University.[Unpublished].

Mabogunje, A.L (1989). DIFFRI and strategies for integrated rural development. A paper presented at a National Seminar on Integrated Rural Development. Lagos

Mathewos Tadesse. (2006). The challenges and Prospects of community radio in Ethiopia: The case of Harar Community Radio. Addis Ababa University.[Unpublished].

Mentamer Legesse (2017). Assessing Communication Effectiveness of Addis Ababa University Community Radio for the Students. Addis Ababa University. [unpublished].

Mohan Dhamotharan. (2009). Handbook on Integrated Community Development-Seven D Approach to Community Capacity Development. Asian Productivity Organization. Japan. ISBN: 92-833-7085-6

Mulatu Alemayehu. (2018). "Handbook of Communication for Development and Social Change." In Community radio in Ethiopia: A discourse of peace and conflict reporting". Addis Abeba University., by J. Servaes. https://doi.org/10.1007/978-981-10-7035-8_37-1. 
Nigussie Meshesha. (2014). Media and Politics in Ethiopia: A Critical Analysis. Ethiop.j.soc.lang.stud. 1(2), 74-95. eISSN: 2408-9532

Servaes J. (1996). Communication for development and social change. New Delhi : Sage.

Tabing, L. (2002). How to Do Community Radio: a Primer for Community Radio Operators, the United Nations Educational, Scientific and Cultural Organization (UNESCO): New Delhi.

UNESCO. (2002). Chapter 10.UNESCO's Contributions to Cultural Diversity and Communication for Development. In: SERVAES, J. (ed.) Approaches to Development Communication, Paris: UNESCO.

UNESCO. (2015). Galuh II no 5. KebayoranBaru Jakarta Indonesia: DKI Jakarta 12110.

Waisbord, Silvio. (2000). "Family Tree of Theories, Methodologies, and Strategies in Development Communication: Convergences and Differences.” Rockefeller Foundation: New York. (http://www.communicationforsocialchange.org/pdf/familytree.pdf. Last accessed August 15, 2008.)

Web: http://www.eba.gov.et/index.php/2013-11-03-08-41-12/2013-11-03-08-48-13 